\title{
Toxin Production of Faecal Strains of Clostridium welchii
}

\author{
D. J. E. PRICE,* M.B., B.S. ; R. A. SHOOTER,* M.D., M.R.C.P.
}

Brit. med. F., 1964, 2, 1176-1177

Clostridium welchii is a normal inhabitant of the large intestine of man. It can be isolated from the skin around the anus and frequently from the skin some distance away. It is often found in the air and dust of hospital wards. Despite the ubiquity of the organism, gas gangrene is rare. The probable reason for this is that clostridia require a marked reduction in oxygen tension before their spores will germinate and before they will form toxin. This condition, together with the presence of clostridia, is rarely present in the post-operative period.

It has been suggested that ian important reason may be that clostridia in the faeces, and in the environment, produce relatively little toxin as compared with strains from actual infections: To investigate this possibility 200 strains of $\mathrm{Cl}$. welchii isolated from patients' faeces have been examined for their toxin-producing power, and have been compared with 11 strains of the same organism isolated from the lesions of patients with gas gangrene.

\section{Materials and Methods}

The patients from whom stools were obtained were awaiting surgery in general surgical, orthopaedic, thoracic, and gynaecological wards.

Isolation of $\mathrm{Cl}$. welchii.-Faeces were inoculated into Robertson's meat broth containing $200 \mu \mathrm{g}$. of neomycin per $\mathrm{ml}$. Subcultures were made after 12 hours' incubation on modified Nagler plates containing egg yolk as a source of lecithin, and these plates were incubated in partially anaerobic McIntosh and Filde jars. $\mathrm{Cl}$. welchii is not a strict anaerobe and the small amount of oxygen present inhibited strict anaerobes, including Cl. oedematiens (Willis, 1960). Nagler-positive (lecithinaseproducing) colonies were identified as those of $\mathrm{Cl}$. welchii by the appropriate fermentation reactions.

Preparation of Toxin.-The most important toxin of the type A $\mathrm{Cl}$. welchii strains which are responsible for gas gangrene is thought to be the $\alpha$-toxin, which is known to be a lecithinase. MacFarlane and Knight (1941) showed that in Robertson's meat medium a maximum concentration of this toxin is found after six hours' growth, and Gale and van Heyningen (1942) showed that the yield can be increased by raising the glucose concentration to $300 \mathrm{mg} . / 100 \mathrm{ml}$. Toxin was therefore prepared by inoculating glucose-Robertson's medium with 3 drops of culture and incubating at $37^{\circ} \mathrm{C}$. for six hours, followed by filtration through a Seitz filter. The yield of toxin was found not to be dependent on the size of the inoculum.

Assay of $\alpha$-Toxin.-Toxin was assayed by the method described by MacFarlane et al. (1941). Set volumes of toxin were incubated with set volumes of egg-yolk suspension and varying concentrations of standardized $\mathrm{Cl}$. welchii antitoxin. The end-point was taken as the lowest antitoxin concentration that inhibited lecithin breakdown. As the concentration of antitoxin was known the amount of $\alpha$-toxin present could be calculated.

\section{Results}

Strains of Cl. welchii from Stools.-The 200 strains of $\mathrm{Cl}$. welchii which were examined came from 154 patients. From a further 15 patients presumptive $\mathrm{Cl}$. welchii were isolated, but not in pure culture. From 68 patients the organism was not isolated. The results of the assay of $\alpha$-toxin are given in the Chart. The majority of strains produced concentrations of toxin of from 0.02 to 0.5 unit per ml., with a range of less than 0.005 unit $/ \mathrm{ml}$. up to 2 units $/ \mathrm{ml}$. As controls two strains known to produce approximately 5 units of $\alpha$-toxin per ml. were tested and were found to yield 4.5 and 4.7 units $/ \mathrm{ml}$.

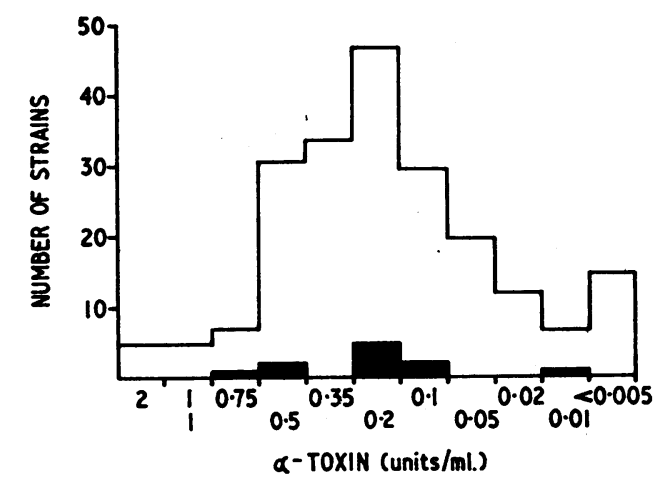

$\alpha$-Toxin production of strains of $\mathrm{Cl}$. welchii from faeces (unshaded area) and from patients with gas gangrene (black areas).

Strains of $\mathrm{Cl}$. welchii from Lesions of Patients with Gas Gangrene.-Eleven strains of $\mathrm{Cl}$. welchii from patients with gas gangrene were examined. Two of these strains had been freshly isolated. The remainder were of varying ages, five of them being the strains described by Evans (1945). These strains had been freeze-dried in horse serum. The toxin production of the 11 strains is shown in the Chart. It will be seen that there was a range of 0.01 to 0.75 unit of toxin per $\mathrm{ml}$. The range for the five strains previously described by Evans (1945) was 0.01 to 0.48 unit per ml., as compared with the 1945 range of 0.1 to 0.85 unit per $\mathrm{ml}$.

\section{Discussion}

The finding that among commensal strains of $\mathrm{Cl}$. welchii there were many that were able to form appreciable amounts of $\alpha$-toxin is compatible with the widely held view that if gas gangrene occurs in civil or military practice the infecting organism is often derived from the patient. Our commensal strains varied in their ability to form toxin, but many of them produced toxin as well as or better than the strains isolated from patients with gas gangrene. It may be objected that with two exceptions our strains from infections were old strains, but a comparison of our results with those obtained by Evans (1945) suggests that there had been relatively little loss of toxin-forming capacity during storage.

The results do not support the view that gas gangrene is uncommon in surgical practice because the strains of $\mathrm{Cl}$. welchii in patients' faeces produce relatively little $\alpha$-toxin. They do, however, lend support to the view expressed by Williams et al.

\footnotetext{
* From the Department of Bacteriology, St. Bartholomew's Hospital,
} London. 
(1960) that there is no more need to isolate a patient with gas gangrene than there is to isolate a patient because he has clostridia in his faeces.

\section{Summary}

Two hundred strains of $\mathrm{Cl}$. welchii isolated from the faeces of surgical patients were tested for the production of $\alpha$-toxin. The majority of strains produced concentrations of toxin from 0.02 to 0.5 unit $/ \mathrm{ml}$, with a range of less than $0.005 \mathrm{unit} / \mathrm{ml}$. up to 2 units $/ \mathrm{ml}$.

Eleven strains isolated from the lesions of patients with gas gangrene were found to produce toxin within a range of 0.01 to $0.75 \mathrm{unit} / \mathrm{ml}$.

It is suggested that these results are compatible with the view that the infecting organism in gas gangrene is often derived from the patient, and that they do not support the opinion that the reason why gas gangrene is rare in surgical practice is because faecal strains of $\mathrm{Cl}$. welchii produce relatively little toxin.

We would like to acknowledge the help we have had from Dr. G. Harriet Warrack both in the provision of materials for the assay of $\alpha$-toxin and in instruction in their use. We are also indebted to Professor D. G. Evans, F.R.S., for advice, and would like to thank him and Dr. E. G. Lowbury for supplying us with strains of Cl. welchii from patients.

\section{REFERENCES}

Evans, D. G. (1945). 7. Path. Bact., 57, 75

Gale, E. F., and van Heyningen, W. E. (1942). Biochem. 7., 36, 624 MacFarlane, R. G., and Knight, B. C. J. G. (1941). Ibid., 35, 884 - Oakley, C. L., and Anderson, C. G. (1941). F. Path. Bact., 52, 99 Williams, R. E. O., Blowers, R., Garrod, L. P., and Shooter, R. A. (1960). Hospital Infection, Causes and Prevention. Lloyd Luke, (1960).

Willis, A. T. (1960). Anaerobic Bacteriology in Clinical Medicine. Butterworth, London.

\section{Medical Memoranda}

\section{Multiple Deficiency State Associated with Isoniazid Therapy}

\author{
Brit. med. F., 1964, 2, 1177-1178
}

The following report concerns a patient who developed peripheral neuropathy, pellagra-like skin lesions, and a toxic psychosis while receiving isoniazid for pulmonary tuberculosis.

\section{CASE History}

A 53-year-old widow was found to have pulmonary tuberculosis in April 1962 and was treated in hospital for this condition until November of that year. Her weight on admission was 9 st. (57.2 $\mathrm{kg}$.). Chemotherapy had begun with a daily dosage of streptomycin 0.75 g., P.A.S., 12 g., and isoniazid, $300 \mathrm{mg}$. Because of allergic skin reactions streptomycin and P.A.S. had to be discontinued. Cycloserine was substituted but was stopped after she had had a grand-mal epileptic fit. She was eventually discharged home on isoniazid, $150 \mathrm{mg}$., and ethionamide, $250 \mathrm{mg}$., both twice daily, having received this combination for two months without adverse effect. Her weight on discharge was $10 \mathrm{st.} 7 \mathrm{lb}$. (66.7 kg.).

In February 1963 she developed influenza and laryngitis, but no increase in tuberculous activity was detectable on, radiography. A depressive illness supervened with loss of appetite and increasing lethargy, and she spent much of the day in bed. Later she complained of a sore tongue and mouth, burning and tingling in the hands and feet, and difficulty in walking. At times there were episodes of confused behaviour and night wandering. Her memory deteriorated and she was sometimes incontinent of urine. She had always been of an anxious, worrying disposition and had had a previous depressive illness in 1961.

She was admitted to hospital for investigation on 20 March 1963. She was of small stature and had obviously lost weight. She weighed 7 st. $7 \mathrm{lb}$. (47.7 kg.). Physical examination revealed a marked reddish-brown pigmentation of the skin of the face and neck, the hands, and the legs below the knee. The skin of the trunk, where it had been subjected to pressure from underclothing, was also affected. The tongue was dry and red, and there was angular stomatitis. The other abnormal physical signs were found in the nervous system. The cranial nerves were normal. Muscle tone and power were slightly diminished in the arms and legs. No loss of sensation to light touch, pain, or temperature could be elicited, but the sense of joint position was impaired in the legs, and there was lack of co-ordination on finger-nose and heel-knee tests. This increased when her eyes were closed. Her gait was ataxic and she could not walk unaided. The abdominal reflexes were absent, the plantar responses equivocal, but the deep reflexes were present and equal. Mentally she was disinterested and apathetic, with little spontaneity of talk or activity. She complained of depression and lack of energy. She was disorientated in time and place, though she realized she was in hospital. Recent memory was impaired and there was patchy loss for remote events. She was able to co-operate satisfactorily during the physical examination. At night she was restless, talkative, and confused and required sedation.

Radiograph of the chest showed fibrosis in the upper zone of the right lung. Haemoglobin was $84 \%$; white blood-cells 8,000 c.mm.; normal differential ; E.S.R. was $10 \mathrm{~mm}$. in one hour ; film showed normal red blood cells. Blood urea was $27 \mathrm{mg} . / 100 \mathrm{ml}$; ; serum electrolytes were normal ; fasting blood sugar was $78 \mathrm{mg} . / 100 \mathrm{ml}$. W.R. was negative. Serum vitamin-B $B_{12}$ assay was $750 \mu \mu \mathrm{g} . / \mathrm{ml}$. Blood pyruvic acid, $1.0 \mathrm{mg} . / 100 \mathrm{ml}$. Urine was acid with no protein, sugar, or ketones. Urinary 17-hydroxycorticosteroids were 5 mg. $/ 24$ hours.

The administration of isoniazid and ethionamide, which had been continued up to her admission to hospital, was stopped. The patient was then treated with nicotinic acid, $100 \mathrm{mg}$., three times daily, intravenous vitamin-B complex (" parentrovite."), and a full and varied diet. After three days there were no more confusional episodes and after a week the tingling in the arms and legs had disappeared. She felt more cheerful and showed more interest in her surroundings. After two weeks skin pigmentation was about back to normal and she had gained half a stone in weight.

\section{COMMENT}

This patient is presented as a case of a multiple deficiency state associated with the administration of isoniazid. The increased incidence of peripheral neuropathy, pellagra, and mental changes complicating isoniazid therapy in patients with existing malnutrition has been frequently commented upon (Wood, 1955 ; Haynes, 1958 ; Money, 1959). On standard dosages of isoniazid (up to $5 \mathrm{mg}$. $/ \mathrm{kg}$.) peripheral neuropathy is a rare complication, becoming increasingly frequent with higher doses (Devadatta, Gangadharam, Andrews, Fox, Ramakrishnan, Selkon, and Velu, 1960). Jackson (1957), however, has reported toxic psychoses on standard dosages, even in the absence of malnutrition. 